
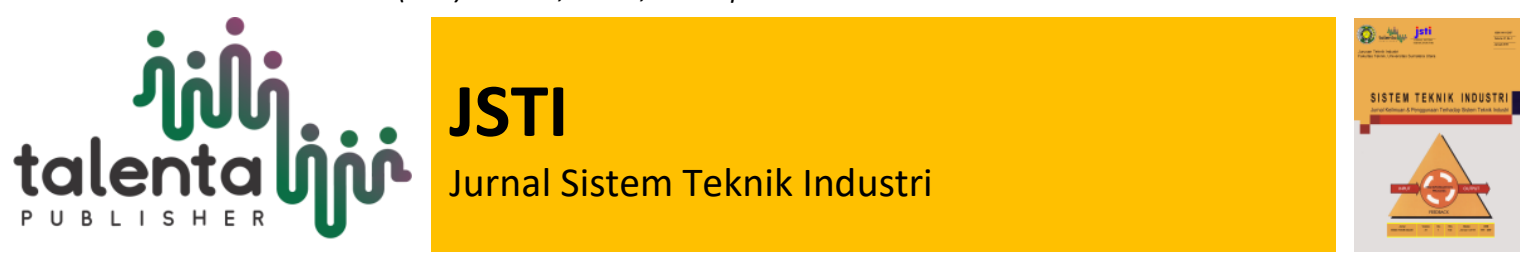

\title{
Preventive Maintenance Scheduling on Belt Conveyor Using Failure Mode Effect and Criticality Analysis
}

\author{
Fernado Putra Kristian ${ }^{1}$, Julius Mulyono ${ }^{2}$, Hadi Santosa ${ }^{3}$ \\ ${ }^{1,2,3}$ Department of Industrial Engineering, Faculty of Engineering, Universitas Katolik Widya Mandala \\ Surabaya, Surabaya
}

\begin{abstract}
PT. X is a services and manufacturing company. PT. Y is one of some of industrial companies use the services of PT. X, is one of the biggest chemical fertilizer producer in Southeast Asia. PT Y uses 66 belt-conveyors for distributing the material. In order to arrange maintenance schedule, used preventive maintenance calculations using Failure Mode Effect and Critically Analysis method (FMECA). Preventive maintenance is used to schedule the maintenance of the conveyor belt's components (belt and primary cleaner). Data analysis obtained a critical belt values are $2.521 \times 10^{-3}$ and $1.863 \times 10^{-3}$, respectively, on the primary cleaner component. Furthermore, effective maintenance and evaluation time intervals which obtained for belt components is indicating operation time with $92 \%$ reliability level or about 215 hours.
\end{abstract}

Keyword: Maintenance, Scheduling, Failure Mode Effect Criticality and Analysis (FMECA), Critical Components, Cleaner

\begin{abstract}
Abstrak. PT. X adalah sebuah perusahaan di bidang jasa dan manufaktur. PT. Y adalah perusahaan pengguna jasa dari PT. X, sebuah perusahaan penghasil pupuk kimia terbesar se-Asia Tenggara. PT. Y menggunakan belt conveyor dalam mendistribusikan material. PT. $Y$ mempercayakan perawatan 66 belt conveyor kepada PT. X. Penyusunan jadwal pemeliharaan/perawatan dilakukan dengan perhitungan preventive maintenance memakai metode failure mode effect and criticality analysis (FMECA). Penjadwalan pemeliharaan/perawatan komponen belt conveyor (belt dan primmary cleaner) menggunakan konsep preventive maintenance. Pengolahan data menghasilkan nilai critical belt sebesar 2,521 $\times 10^{-3}$ dan 1,863 $\times 10^{-3}$ pada komponen primmary cleaner. Interval waktu perawatan dan level keandalan yang efektif menunjukkan waktu operasi dengan reliability $92 \%$ atau sekitar 215 jam.
\end{abstract}

Kata Kunci: Penjadwalan, Maintenance, Failure Mode Effect Criticality and Analysis (FMECA), Komponen Kritis, Cleaner.

Received 06 October 2020 | Revised 15 January 2021 | Accepted 26 January 2021

\section{Introduction}

A company must get the process efficiently and effectively, and resulting in the highest profit. Maintenance is a supporting factor in increasing the productivity of a company, especially those

*Corresponding author at: Kalijudan Street Number 37 Surabaya 60114, East Java, Indonesia

E-mail address: juliusnyamulyono@ukwms.ac.id https://doi.org/10.32734/jsti.v23i1.4368 
engaged in manufacturing. The availability of a good machine maintenance system can increase quality and productivity, by minimizing downtime and maximizing effectiveness [3][4].

PT. $\mathrm{X}$ is a company engaged in services and manufacturing. One of the member of PT. X, is PT. $\mathrm{Y}$, which is the largest chemical fertilizer factory in Southeast Asia. PT. Y uses several transportation methode, for delivering the material from the ship at the port to the storage area. One of the transportation tool is the belt conveyor.

Routine maintenance that is carried out aims to reduce the frequency of damage to the belt conveyor, which is applied to 66 conveyor belts, namely 2 times a month. The material transported from the ship to the factory, package in bulks, are sulfur and phosphate. Damage or failure of the conveyor causes PT. Y will be penalized for demurrage or the length of time using the container exceeds the provisions.

In this article, we arrange the preventive maintenance schedule using the concept of failure mode effect and criticality analysis (FMECA) on the belt conveyor, as the object of this research. ElDogdog [2] states that FMECA can be applied in designing of the reliability center maintenance concept. On all belt conveyor, is in a production line with a high level of utilities, for screening the sulfur. The belt conveyor needs to get special treatment to avoid any downtime.

\section{Literature Review}

\subsection{Preventive Maintenance}

Preventive maintenance is a systematic, economical way of keeping production equipment running and extending its service life. Preventive maintenance aims to obtain a optimum maintenance level for all production equipment in order to obtain the highest quality [5][6].

Preventive maintenance is also means as maintenance throughout the range or duration, paying attention to other things to minimize the opportunity for other components to exceed the provisions. Preventive maintenance is carried out when the failure rate increases, as shown in the bathtub graph, and the formula is:

$$
C(T p)=\frac{\text { ff } \times(1-R(T p))+C p \times R(T p)}{T p \times R(T p)+M(T p) \times(1-R(T p))}
$$

This cutting region is often called the wear out area. to calculate the total cost per unit of time, is used:

$$
M(T p)=\int_{0}^{T p} \frac{t f(t) d t}{(1-R(T p))}
$$

$$
\begin{array}{ll}
C(T p) & =\text { total cost } \\
C p & =\text { preventive maintenance cost } \\
C f & =\text { corrective maintenance cost }
\end{array}
$$


$T p \quad=$ interval between preventive maintenance

$R(T p) \quad=$ reliability level

$M(T p)=$ Maintainability

Determining the amount of preventive maintenance by:

$$
\mathrm{nT}<\mathrm{t}<(\mathrm{n}+1) \mathrm{T} ; \mathrm{n}=0,1,2
$$

$\mathrm{Rm}(\mathrm{t})=$ reliability level.

$\mathrm{R}(\mathrm{t}) \mathrm{n}=$ The probability of the $\mathrm{n}$ value of the maintenance interval

$\mathrm{R}(\mathrm{t}-\mathrm{nT})=$ The probability of the $\mathrm{t}$ until $\mathrm{nT}$ value of the maintenance interval.

\subsection{Reability}

The reliability is the probability that the equipment will work properly, functioning over time $(\mathrm{t})$ or even more. The reliability level is expressed by [1]:

$$
R(t)=1-F(t)=\int_{t}^{\sim} f(t) d t
$$

$f(t) \quad=$ probability density function

$R(t) \quad=$ probability the equipment perform at interval $\mathrm{t}$

$F(t)=$ probability the equipment do not perform at interval $\mathrm{t}$

The probability density function of 2-parameters Weibull is [1]:

$$
\begin{aligned}
& f(t)=\frac{\beta}{\eta}\left(\frac{t}{\eta}\right)^{\beta-1} \exp \left[-\left(\frac{t}{\eta}\right)^{\beta}\right] \\
& f(T) \geq 0, \eta>0, t \geq 0, \beta>0
\end{aligned}
$$

$\eta=$ Eta (scale parameter)

$\beta=$ Beta (shape parameter)

The meantime between failure (MTBF) is:

$$
\mathrm{MTBF}=\gamma+\Gamma\left(\frac{1}{\beta}+1\right)
$$

$\gamma=$ Gamma (location parameter)

The probability density function of 3-parameters Weibull is:

$$
\begin{aligned}
& f(t)=\frac{\beta}{\eta}\left(\frac{t-\gamma}{\eta}\right)^{\beta-1} \exp \left[-\left(\frac{t-\gamma}{\eta}\right)^{\beta}\right] \\
& r(x)=\int_{0}^{x} y^{x-1}-e^{-y} d y
\end{aligned}
$$




\subsection{Failure mode Effect \& Criticality Analysis (FMECA)}

Rausand stated that FMECA is a methode for identifying and analyze [7]:

1. Possible damage

2. Other effects of damage, using monitoring the severity and probability level.

FMECA consists of two steps of analysis, namely Failure Mode and Effect Analysis (FMEA), which consists of four stages: system determination, system function block diagrams, identification of the mode of damage and identification of the consequences. The Criticality Analysis (CA) stages include the calculation of the criticality value and the calculation of the failure rate [8].

Table 1 Criticality

\begin{tabular}{lll}
\hline \multicolumn{2}{c}{ CRITICALITY } & Risk or Hazard \\
\cline { 1 - 2 } $\begin{array}{l}\text { Degree of } \\
\text { criticality }\end{array}$ & \multicolumn{1}{c}{ Value } & \\
\hline Minor & $0-30$ & Acceptable \\
\hline Medium & $31-60$ & Tolerable \\
High & $61-180$ & \\
\hline Very High & $181-252$ & \\
Critical & $253-324$ & Unacceptable \\
Very critical & $>324$ & \\
\hline
\end{tabular}

Table 2 Occurrence Rating

\begin{tabular}{cll}
\hline Rating & Probability of occurrence & \multicolumn{1}{c}{$\begin{array}{c}\text { Failure } \\
\text { probability }\end{array}$} \\
\hline 10 & Very High (VH) & $>1$ in 2 \\
\hline 9 & & 1 in 3 \\
8 & High (H) & 1 in 8 \\
7 & & 1 in 20 \\
\hline 6 & & 1 in 80 \\
5 & Moderate (M) & 1 in 400 \\
4 & & 1 in 8000 \\
\hline 3 & & 1 in 15000 \\
2 & Low (L) & 1 in 150000 \\
1 & & $<1$ in 150000 \\
\hline
\end{tabular}

Table 3 Severity Rating

\begin{tabular}{cl}
\hline Rank & \multicolumn{1}{c}{ Verbal Criteria } \\
\hline 1 & Negligible severity \\
\hline 2 & Mild severity \\
3 & \\
\hline 4 & \\
5 & Mild severity \\
6 & \\
\hline
\end{tabular}




\begin{tabular}{cl}
\hline 7 & High severity \\
8 & \\
\hline 9 & Catastrophic: potential \\
10 & safety problem \\
\hline
\end{tabular}

Table 4 Detection Rating

\begin{tabular}{lll}
\hline Rank & \multicolumn{1}{c}{ Verbal Criteria } & \multicolumn{1}{c}{ Failure probability } \\
\hline 1 & Almost Certain & 1 in 1000000 \\
2 & Very High & 1 in 20000 \\
3 & High & 1 in 4000 \\
4 & Moderate High & 1 in 1000 \\
5 & Moderate & 1 in 400 \\
6 & Low & 1 in 80 \\
7 & Very Low & 1 in 40 \\
8 & Remote & 1 in 20 \\
9 & Very Remote & 1 in 8 \\
10 & Absolute Uncertain & 1 in 2 \\
\hline
\end{tabular}

\section{Literature Review}

\subsection{Data Collecting}

Primary research data were obtained directly from original sources, by interviewing a person or any community. The purpose is to answer the research questions and doing an observation. Secondary research data is obtained indirectly or through intermediary media. The required data are:

1. Breakdown time of the belt conveyor.

2. List of the belt conveyor components.

3. Repairing-Time duration.

4. The Critical component of the belt conveyor.

\subsection{Failure Effect Identification}

Identification of the failure effect aims to determine the components, i.e. the object of this research, and looking for the causes, impacts, and forms of failure that occur in the belt conveyor components.

\subsection{Determine the Critical Component}

At this stage, the RPN value is obtained by multiplying $\mathrm{S} \times \mathrm{O} \times \mathrm{D}$. The next step is FMECA analysis. The component with the largest RPN value is the critical component. 


\subsection{Preventive Maintenance Scheduling}

After collecting data on critical components of the conveyor belt, the average time between damage of the components is calculated. This process is carried out with a distribution approach from the damage data obtained. Maintenance schedules are prepared by taking into account the desired level of reliability.

\section{Result and Discussion}

\subsection{Risk Priority Number (RPN) of the Belt Conveyor Component}

By doing some observations [9], the RPN value for each component is obtained as follows:

Table 5 RPN Value of the Belt Conveyor Component

\begin{tabular}{clc}
\hline No. & \multicolumn{1}{c}{ Component } & RPN \\
\hline 1 & Pulley & 24 \\
2 & Tension Roll & 24 \\
3 & Stop End & 12 \\
4 & Hopper inlet & 24 \\
5 & Cut Hopper Inlet & 24 \\
6 & Skirtboard & 24 \\
7 & Rubber Seal & 36 \\
8 & Impact Roll & 36 \\
9 & Carry Roll & 48 \\
10 & Hopper Outlet & 18 \\
11 & Primmary Cleaner & 60 \\
12 & Head Pulley & 36 \\
13 & Secondary Cleaner & 40 \\
14 & Snub Head Pulley & 24 \\
15 & Bend 1 Pulley & 24 \\
16 & Counter Weight & 27 \\
17 & Take Up & 24 \\
18 & Bend pulley & 24 \\
19 & Inverse Roll & 18 \\
20 & Tilting Roll & 18 \\
21 & Return Roll & 18 \\
22 & V-scrapper & 36 \\
23 & Snub Tail Pulley & 18 \\
24 & Belt & 96 \\
\hline
\end{tabular}

\subsection{Determine the Critical Component}

According to the FMEA analysis, which resulting the RPN value, it can be seen that the belt component and primmary cleaner have the highest value. The calculation of the critical value of the components as seen in the table below.

Table 6 Critical Component Data

\begin{tabular}{lc}
\hline \multicolumn{1}{c}{ Component } & Failure mode critical $(\mathrm{Cm})$ \\
\hline Belt & $2,521 \times 10^{-3}$ \\
Primmary Cleaner & $1,863 \times 10^{-3}$ \\
\hline
\end{tabular}




\subsection{Mean Time Between Failure (MTBF)}

We used the records of belt conveyor breakdowns on interval of December 2018 to July 2019.

Table 7 Records of Belt Conveyor Breakdown

\begin{tabular}{cllccc}
\hline No. & \multicolumn{1}{c}{ Down } & \multicolumn{1}{c}{ Up } & $\begin{array}{c}\text { Maintenance } \\
\text { Time (hours) }\end{array}$ & MTBF (hours) & $\begin{array}{c}\text { Operation } \\
\text { time (hours) }\end{array}$ \\
\hline 1 & $1 / 3 / 1910: 32$ & $1 / 3 / 1915: 02$ & 4,50 & 0 & 20,23 \\
2 & $1 / 4 / 1911: 16$ & $1 / 4 / 1916: 01$ & 4,75 & 24,98 & 65,32 \\
3 & $1 / 7 / 199: 20$ & $1 / 7 / 1914: 30$ & 5,17 & 70,48 & 264,08 \\
4 & $1 / 18 / 1914: 35$ & $1 / 18 / 1919: 50$ & 5,25 & 269,33 & 328,95 \\
5 & $2 / 1 / 1912: 47$ & $2 / 1 / 1917: 47$ & 5,00 & 333,95 & 69,05 \\
6 & $2 / 4 / 1914: 50$ & $2 / 4 / 1919: 35$ & 4,75 & 73,80 & 597,60 \\
7 & $3 / 1 / 1917: 11$ & $3 / 1 / 1922: 26$ & 5,25 & 602,85 & 230,85 \\
8 & $3 / 11 / 1913: 17$ & $3 / 11 / 1918: 07$ & 4,83 & 235,68 & 235,63 \\
9 & $3 / 27 / 197: 45$ & $3 / 27 / 1912: 45$ & 5,00 & 240,63 & 187,58 \\
10 & $4 / 4 / 198: 20$ & $4 / 4 / 1913: 00$ & 4,67 & 192,25 & 68,58 \\
11 & $4 / 7 / 199: 35$ & $4 / 7 / 1914: 05$ & 4,50 & 73,08 & 95,42 \\
12 & $4 / 11 / 1913: 30$ & $4 / 11 / 1918: 15$ & 4,75 & 100,17 & 15,75 \\
13 & $4 / 12 / 1910: 00$ & $4 / 12 / 1915: 20$ & 5,33 & 21,08 & 426,25 \\
14 & $4 / 30 / 199: 35$ & $4 / 30 / 1914: 10$ & 4,58 & 430,83 & 309,00 \\
15 & $5 / 13 / 1911: 10$ & $5 / 13 / 1916: 00$ & 4,83 & 313,83 & 26,67 \\
16 & $5 / 14 / 1918: 40$ & $5 / 14 / 1923: 10$ & 4,50 & 31,17 & 59,78 \\
17 & $5 / 17 / 1910: 57$ & $5 / 17 / 1915: 57$ & 5,00 & 64,78 & 135,22 \\
18 & $5 / 23 / 197: 10$ & $5 / 23 / 1912: 10$ & 5,00 & 140,22 & 141,92 \\
19 & $5 / 29 / 1910: 05$ & $5 / 29 / 1915: 15$ & 5,17 & 147,08 & 305,08 \\
20 & $6 / 11 / 198: 20$ & $6 / 11 / 1913: 35$ & 5,25 & 310,33 & 553,42 \\
21 & $7 / 4 / 1915: 00$ & $7 / 4 / 1919: 40$ & 4,67 & 558,08 & 260,00 \\
22 & $7 / 15 / 1914: 40$ & $7 / 15 / 1919: 25$ & 4,75 & 264,75 & 60,83 \\
23 & $7 / 18 / 198: 15$ & $7 / 18 / 1913: 25$ & 5,17 & 66,00 & 0,00 \\
\hline
\end{tabular}

\subsection{Determination of Reliability Parameters of the Belt Component}

After we got the MTBF and repairing time, the reliability parameters are determine using Weibull++6. There are three test parameters to determine the type of distribution, namely Average Good Fitness (AvGOF), Average of Plot (AvPlot), and Likelihood Function Ratio (LKV).

Table 8 The Probability Distribution of the MTBF of the Belt Component

\begin{tabular}{ccccc}
\hline Distribution & AvGOF & AvPLOT & LKV & Rank \\
\hline Exponential 1 & 12,169 & 4,619 & $-139,38$ & 4 \\
Exponential 2 & 6,057 & 4,202 & $-137,02$ & 2 \\
Normal & 10,835 & 5,656 & $-143,39$ & 6 \\
Lognormal & 15,467 & 4,494 & $-139,27$ & 5 \\
Weibull 2 & 7,825 & 3,711 & $-138,56$ & 3 \\
Weibull 3 & 1,154 & 3,366 & $-138,11$ & 1 \\
\hline
\end{tabular}

Based on the results of the distribution ranking in Table 8, the distribution of the MTBF of the belt components is Weibull 3 parameters. The paramaters are $\beta=0,9798, \gamma=206,697$, and $\eta=$ 12,644. Using these data, we got the average of the MTBF of the belt component is about 220 hours. 


\subsection{Determination of Maintainability Parameters of the Belt Component}

Based on the maintainance time on table 7 , we determine the maintainability distribution using Weibull++6. The result as shown in table below.

Table 9 The Probability Distribution of the MTBF of the Belt Component

\begin{tabular}{ccccc}
\hline Distribution & AvGOF & AvPLOT & LKV & Rank \\
\hline Exponential 1 & 99,999 & 33,817 & $-63,308$ & 6 \\
Exponential 2 & 83,221 & 11,103 & $-2,051$ & 5 \\
Normal & 13,389 & 4,832 & $-1,997$ & 3 \\
Lognormal & 13,214 & 4,778 & $-1,987$ & 2 \\
Weibull 2 & 41,418 & 6,521 & $-2,702$ & 4 \\
Weibull 3 & 6,121 & 4,099 & $-1,624$ & 1 \\
\hline
\end{tabular}

Based on the results of the distribution ranking in Table 9, the distribution of the MTBF of the belt components is Weibull 3 parameters. The paramaters are $\beta=2,2034, \gamma=0,6877$, and $\eta=$ 4,2963 . Using these data, we got the average of the maintainability of the belt component is about 5 hours.

\subsection{Determination of Operation Time Parameters of the Belt Component}

Based on the down and up time on table 7, we determine the operation time distribution using Weibull++6. The result as shown in table below.

Table 10 The Probability Distribution of Operation Time of the Belt Component

\begin{tabular}{ccccc}
\hline Distribution & AvGOF & AvPLOT & LKV & Rank \\
\hline Exponential 1 & 10,730 & 4,101 & $-138,85$ & 4 \\
Exponential 2 & 6,223 & 4,154 & $-137,07$ & 3 \\
Normal & 18,626 & 5,661 & $-143,39$ & 6 \\
Lognormal & 17,193 & 4,624 & $-139,32$ & 5 \\
Weibull 2 & 4,106 & 3,554 & $-138,34$ & 2 \\
Weibull 3 & 1,193 & 3,373 & $-138,07$ & 1 \\
\hline
\end{tabular}

Based on the results of the distribution ranking in Table 10, the distribution of the Operation time of the belt components is Weibull 3 parameters. The paramaters are $\beta=0,9508, \gamma=204,9817$, and $\eta=8,9987$. Using these data, we got the average of the MTBF of the belt component is about 215 hours.

\subsection{Determination of the Operating Time}

The component reliability is inversely related to the duration of operation time. The calculation of some operating time values resulting a level of reliability, as shown below. 
Table 11 Determination of the Operating Time according to the Reliability

\begin{tabular}{ccc}
\hline No. & Operation time (hours) & Reliability \\
\hline 1 & 215 & 0,9232 \\
2 & 359 & 0,7851 \\
3 & 503 & 0,6662 \\
4 & 647 & 0,5739 \\
5 & 791 & 0,5023 \\
6 & 935 & 0,4458 \\
7 & 1079 & 0,4004 \\
8 & 1223 & 0,3632 \\
9 & 1367 & 0,3322 \\
10 & 1511 & 0,3060 \\
11 & 1655 & 0,2836 \\
12 & 1799 & 0,2642 \\
13 & 1943 & 0,2473 \\
14 & 2087 & 0,2324 \\
15 & 2231 & 0,2192 \\
16 & 2375 & 0,2074 \\
17 & 2519 & 0,1968 \\
18 & 2663 & 0,1872 \\
19 & 2807 & 0,1785 \\
20 & 2951 & 0,1706 \\
21 & 3095 & 0,1633 \\
22 & 3239 & 0,1567 \\
\hline
\end{tabular}

Using the data in the table above, we get a plot of the relationship between the duration of operation time and the reliability value, as shown in Figure 1.

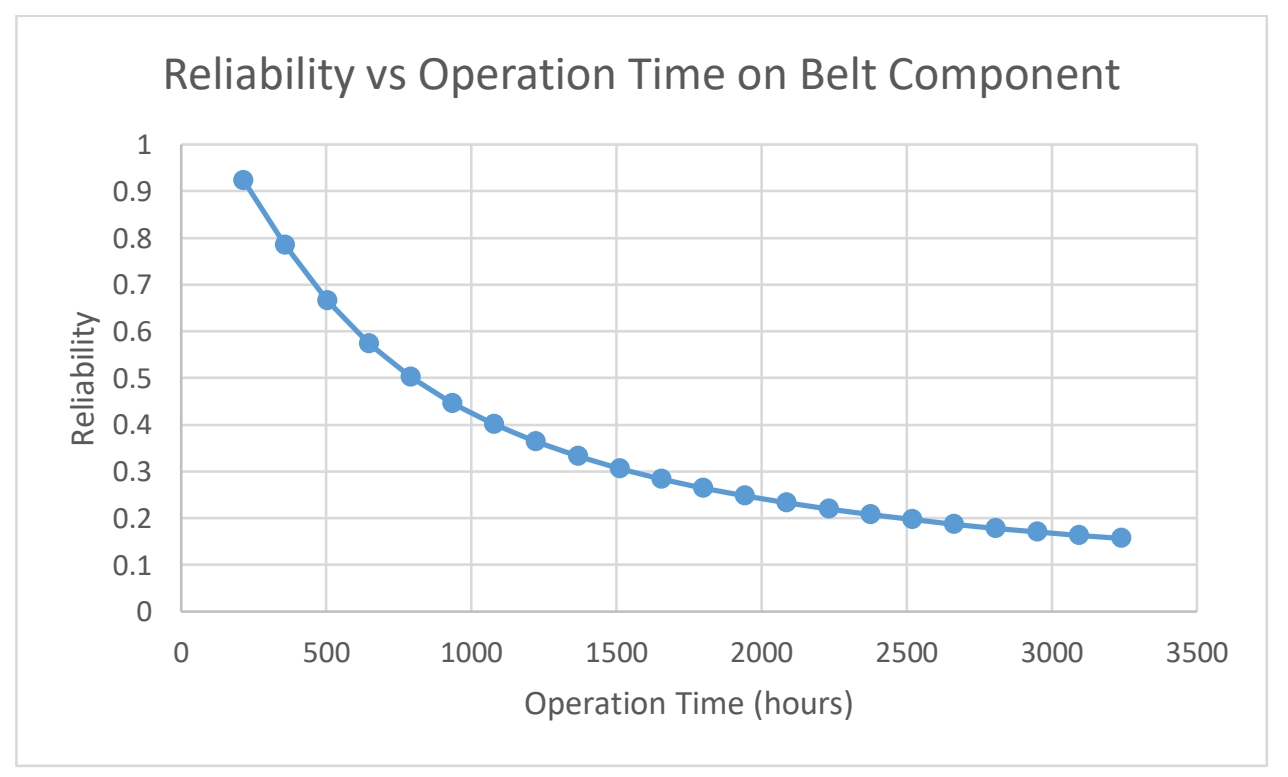

Figure 1 The Relationship between the Duration of Operation Time and the Reliability 


\section{Conclusion}

After performing data processing and analysis, we get the following conclusions. The most critical component of the belt conveyor machine is the primmary cleaner. The belt conveyor have to conduct a maintenance activity after 215 hours operation time. For this condition, the reliability is $92,32 \%$.

\section{REFERENCES}

[1] Ebeling, C. E., An introduction to reliability and maintainability engineering, McGrawHill Education, 2004.

[2] El-Dogdog, Tamer M. ; El-Assal, Ahmed M.; Abdel-Aziz, Islam H.; El-Betar, Ahmed A.; Implementation of FMECA and Fishbone Techniques in Reliability Centred Maintenance Planning, International Journal of Innovative Research in Science, Engineering and Technology, 2016.

[3] Kuncahyo, D. S., Pendekatan Penerapan Total Productive Maintenance (TPM) di Stasiun Press Palm Oil pada Mesin Digester dan Mesin Press PT. Bangkit Giat Usaha Mandiri dengan Menggunakan Indikator OEE dan Metode FMECA (Failure Mode Effect and Critical Analysis), Penelitian dan Aplikasi Sistem dan Teknik Industri, 2015.

[4] Nurprihatin, F., Jodiawan, P., Fernando, N., \& Gurusinga, G. K. K., Usulan Perbaikan Performa Mesin Toelasting Glue dengan Integrasi OEE dan Metode DMAIC (Studi Kasus: Perusahaan Manufaktur Sepatu), Seminar Nasional Teknologi dan Informatika - Muria Kudus University, 2017.

[5] Praja, Ikhsan, Analisis Perawatan Mesin Conveyor Unloading Phosphate Rock Mesir dengan Metode Reliability Centered Maintenance (RCM) (Studi Kasus di PT Petrokimia Gresik), Undergraduate thesis, Universitas Muhammadiyah Gresik, 2019.

[6] Rakhmad, M. B., Optimasi Interval Waktu Perawatan Pencegahan pada Sistem Pemasok Bahan Bakar Turbin Gas dengan Menggunakan Simulasi Monte Carlo, Tesis yang tidak dipublikasikan. Surabaya: Program Studi Magister Manajemen Teknologi ITS, 2011.

[7] Rausand, M., System Analysis Failure Modes, Effects, And Criticality Analysis. System Reliability Theory $2^{\text {nd }}$ Ed., Wiley, 2004.

[8] Sumarta, D. M., Penerapan Metode Failure Mode, Effect and Criticality Analysis (FMECA) pada Drive Station Alat Angkut Konveyor Rel. Infomatek: Jurnal Informatika, Manajemen dan Teknologi, 2017.

[9] Wang, Y. M., Chin, K. S., Poon, G. K. K., \& Yang, J. B., Risk Evaluation in Failure Mode and Effects Analysis using Fuzzy Weighted Geometric Mean - Expert Systems with Applications, 2009. 